\title{
Biopolitical Frames of Impoverished Women in Journalistic Photography about the Bolsa- Família Program ${ }^{1}$ Enquadramentos biopolíticos de mulheres empobrecidas nas imagens fotojornalísticas acerca do Programa Bolsa-Família
}

\begin{abstract}
Ângela Cristina Salgueiro Marques
Doctorate in Social Communication from Federal University of Minas Gerais (UFMG). In 2008 she held a postdoctoral degree working with researchers that integrate the « Groupe de Recherche sur les Enjeux de la Communication" (GRESEC) - Institut de Communicatinons et des Médias, Université Stendhal / Grenoble 3. Collaborate with the Research Group on Democracy and Justice (MARGEM) at the Political Science Department at UFMG. She is co-author of the book Apelos solidarios(Intermeios, 2017), written with Angie Biondi; Diálogos e Dissidências: M. Foucault e J. Rancière (Appris, 2018), with Marco Aurélio Máximo Prado; and Ética, Mídia e Comunicação (Summus, 2018), with Luis Mauro Sá Martino. She is the organizer of the book Vulnerabilidades, justiça e resistências nas interações comunicativas (SELO PPGCOM, 2018). E-mail: angelasalgueiro@gmail.com.
\end{abstract}

Alexei Padilla Herrera

Doctorate candidate in Communication from Federal University of Minas Gerais (UFMG), axe of Communication and Contemporary Sociability, which emphasis on Communicative Processes and Social Practices. Scholarship holder of PECPG/CNPq (2014-2016). Graduated in Social Communication at the Universidad de La Habana(2009). Degree in Digital Journalism from the International Institute of Periodism "José Martí" (2011). His work experience involves organizational communication, web site editing, audiovisual production, journalistic coverage. Topics of interest: Political economy of communication, alternative communication, political communication, public sphere, public deliberation and debate, digital media, interfaces between religion, communication and politics. E-mail: alex6ph@gmail.com.

\begin{abstract}
:
In this article we argue that biopolitical framing of impoverished citizens in the context of the implementation of social politics is a particular modality of moral and simbolic government of collective bodies. The corpus of the research features a total of 120 images related to the Bolsa-Família Program, published between 2003 and 2015 in newspapers such as Folha de S. Paulo, Estado de S. Paulo and $O$ Globo. We investigate the political and ethical dimensions of these images to show how the biopolitical and neoliberal government of collective bodies involves the production of narratives, arguments and discourses that trace distinctions between ways of life considered as dignified and those widely perceived as morally judged as unworthy of consideration and appreciation.
\end{abstract}

\section{Keywords:}

Frameworks; Biopolitics; Photography; Vulnerability; Impoverishment; Women.

${ }^{1}$ This article results from research financed by $\mathrm{CNPq}$ and Fapemig. The author thanks the Phd student Hannah Serrat, who contributed with great suggestions for improving the first version of this text.

INTERIN, v. 25, n. 1, jan./jun. 2020. ISSN: 1980-5276. 


\section{Resumo:}

Neste artigo argumentamos que os enquadramentos biopolíticos de mulheres empobrecidas no contexto da implementação de políticas sociais é uma modalidade particular de governo moral e simbólico de corpos coletivos. O corpus da pesquisa é composto de um total de 120 imagens fotojornalísticas relacionadas ao Programa Bolsa-Família, publicadas entre 2003 e 2015 em jornais como Folha de S. Paulo, Estado de S. Paulo e $O$ Globo. Investigamos as dimensões éticas e políticas dessas imagens para mostrar como o governo biopolítico e neoliberal de corpos coletivos envolve a produção de narrativas, argumentos e discursos que traçam distinções entre formas de vida consideradas dignas de serem reconhecidas e aquelas amplamente percebidas como moralmente desprezáveis e não merecedoras de apreciação e consideração.

\section{Palavras-chave:}

Enquadramentos; Biopolítica; Fotografia; Vulnerabilidade; Empobrecimento; Mulheres.

\section{Introduction}

In this article, by analyzing some photographic images related to the BolsaFamília Program, we intend to argue that an image is political when it allows one to glimpse at the operations that define and influence the interpretation of what's seen. Such operations may be expressed through the relations stablished inside and outside artistic ambit, which pre-configure enunciates, which settle and unsettle discursive and narrative operations between visible and invisible, sayable and unspeakable. As claimed by Rancière, "the image is not merely the visible. It is the dispositive through which the visible is grasped"2 $(2007$, p. 199) and the ways of grasping it. "It is an action that brings the visible into the scene, a knot between the visible and what it says, as also the word and what it allows one to see" (Rancière, 2008, p. 77).

By pointing the frameworks and tensions among them (as they concur to the control of the definition of a governmental social policy), we seek to evidence certain central ideological dimensions that mark the dispute of meanings around the

\footnotetext{
${ }^{2}$ All quotations have been freely translated from vernacular editions indicated in the final references.
} 
journalistic production of images of impoverished subjects and their process of economic and political impoverishment (this process of vulnerability is different from crystallized conceptions of poverty as an inevitable destiny). Among such dimensions we shall highlight, above all, the notions of biopolitics, biolegitimacy and biopotency.

According to Butler, frameworks supposedly help us to distinguish the lives we may appreciate and value from those not deserving to be acknowledged. The terms, the categories, the conventions and general rules that operate in a dispositive of frameworks model and transform, for example, a living being into a subject passible of being acknowledged through a specific form of apprehension, that is, a form of knowledge associated to meaning and to perception, independent from the conceptual forms of mediation among individuals.

Impoverished subjects (mainly women) are usually framed by the media and institutional discourse through evaluative frames that repeat themselves with little difference (Biroli, 2018). However, as frameworks repeat themselves one may verify their flaws and learn the complexity, dissonance, dissent and restlessness of ordinary experience. The framework is not capable of completely containing what is transmits and, therefore, it breaks down whenever one tries to ascribe a definitive organization to its content (Butler, 2015). In this process of continuous rupture, the terms through which the subjects are named and known are produced, displaced, questioned and shifted. It is a matter, according to Butler, of knowing how the operations work, the ones that make certain subjects and groups acknowledgeable and valuable, while others are clearly destitute of respect and consideration.

The object to be analyzed in this work, the appearance of impoverished subjects in the photojournalistic images about government's social policies, involves a delicate operation of framing the framework, that is, an operation of interpellation as we search for the gaps indicating that the framework does not manage to determine precisely what we see, acknowledge and apprehend. Besides, the framework that makes marginalized subjects visible in media discourses usually contributes to intensify their precariousness and concealment.

As highlighted by Butler (2011), normative and media schemes of intelligibility establish what is and what is not to be apprehended and acknowledged

INTERIN, v. 25, n. 1, jan./jun. 2020. ISSN: 1980-5276.

Ângela Cristina Salgueiro Marques; Alexei Padilla Herrera. Biopolitical Frames of Impoverished Women in Journalistic Photography about the Bolsa-Família Program. p. 27-56. DOI 10.35168/1980-5276.UTP.interin.2020.Vol25.N1.pp27-56 
as worthy of being valued. According to her (2015, p. 14), frameworks are power operations: "they do not unilaterally determine the conditions of appearance of the subjects and happenings, however, its finality is to outline the sphere of apparition itself". Frameworks would act, then, for differentiating the lives we may apprehend and value and those we can't. The terms, categories, conventions and general rules at work in the dispositive of frameworks shape, for example, a living being as an acknowledgeable subject through apprehension, that is, a form of knowledge associated to feeling and perception, with no concepts. It is a matter of getting to know how such norms operate in order to make certain subjects acknowledgeable persons while others become definitely harder to acknowledge. The problem, according to Butler (2015, p. 20) "is not only to know how to include more people in the existing rules, but rather to consider how the existing norms ascribe acknowledgement in different forms".

To become visible in a communicative scene involves not only the choice of frames of shared meanings and values - through which the individuals are identified, acknowledged and named - but also the instauration of a conflictive relation in the quest for acknowledgement, legitimacy and autonomy (Biroli, 2018). Visibility, in this case, articulates the existence of a public image with an intersubjective and reciprocal process of enunciation, speech and listening, reception and estrangement.

The premises, judgments, disagreements, values, affective predispositions, etc., that allow social actors to acknowledge and understand the facts and perceptions reveal how the framework is configured as a central organizing idea in processes of discursive unveiling and construction of a political problem and the subjects articulated around it. Didier Fassin (2010) points out that the discussions around the precariousness of self-understanding are fomented by a series of norms and meanings governing the bodies and lives in contemporary times. Therefore, such expressions as "becoming empathetic" "correcting" "resolving" are recurrent in actions of the government and public programs towards impoverished people. According to Fassin, they point to a moral economy that is moved by feelings and emotions that "connect us with the other's malaise and make us wish to correct it" $(2010$, p. 7). At the same time, such mechanisms and norms expose the social games founding social policies

INTERIN, v. 25, n. 1, jan./jun. 2020. ISSN: 1980-5276.

Ângela Cristina Salgueiro Marques; Alexei Padilla Herrera. Biopolitical Frames of Impoverished Women in Journalistic Photography about the Bolsa-Família Program. p. 27-56. DOI 10.35168/1980-5276.UTP.interin.2020.Vol25.N1.pp27-56 
and humanitarian practices, as those dealing with displaced subjects, migrants, homeless, expatriated. "The body became the place of inscribing migratory policies, defining what we call, using a Foucaultian terminology, the biopolitics of alterity" (Fassin, 2001, p. 4).

In this article we argue, along with Foucault, Fassin and Butler, that there is a particular modality of government of collective bodies: the biopolitical framing of impoverished subjects and groups in the context of the implementation of social policies. More specifically, we recur to photojournalistic images of people benefitted by the Bolsa-Família Program - published between 2003 and 2015 in newspapers such as Folha de S. Paulo, Estado de S. Paulo and O Globo - in order to show how the biopolitical government involves the production of narratives, arguments and enunciates that manage to trace distinctions between ways of life considered as dignified and those widely seen as despicable. Biopolitical framing is a technique of government or governmentality that formats the scenes of apparition, preparing them for the definition of exemplary subjects and groups, taken as a parameter, whose project and way of life is seen as the antithesis of deviance, and of existences morally judged as unworthy of consideration and appreciation.

It is very important to make it clear here that the analysis to be accomplished does not intend to reduce all complexity involved in the operation of Bolsa-Família Program to the frameworks produced by the government's Public Communication. In other texts previously developed (Marques, 2008a and b; Marques, 2009; Marques and Farias, 2013) we show how communicative dynamics, the dynamics of producing political autonomy and redistribution of resources associated to the social acknowledgement promoted by this program is essential for the political subjectivation of impoverished women. It is not our intent to depreciate the various merits of this social program, but to evidence the various ambiguities featuring its configuration. The main one is connected to the way how the expansion of neoliberal governmentality comes to produce "a female neoliberal subject" (Rago, 2017). Much of the state propaganda that brings visibility to Bolsa-Família and their indexes of success translate female emancipation as individual and meritorious success, hardly revealing the contingences crossing over the rank of experiences and choices available to the

INTERIN, v. 25, n. 1, jan./jun. 2020. ISSN: 1980-5276.

Ângela Cristina Salgueiro Marques; Alexei Padilla Herrera. Biopolitical Frames of Impoverished Women in Journalistic Photography about the Bolsa-Família Program. p. 27-56. DOI 10.35168/1980-5276.UTP.interin.2020.Vol25.N1.pp27-56 
impoverished woman. The ideological acknowledgement of this woman as responsible, creative and undertaking, influences the way how her life project is configured, adapting it, not rarely, rather to the necessities of neoliberal governmentality than to her own needs.

If, on the one hand, the networks of social care promote the basic conditions for the recipients to construct important dimensions of their citizenship, on the other hand, there are concrete barriers that prevent their political and social inclusion, barriers that yield, above all, from a naturalized understanding that points individuals in situation of poverty as a "useless mass of destitute dependents", incapable of contributing to move the neoliberal wheels of production and consumption.

So, if in the one hand we acknowledge the positive aspects accomplished by the program and their impact in the emancipation of impoverished women, we also realize, along with Butler (2004), Fassin (2010) and Rago (2017), that vulnerability became a hegemonic way of government with strong incidence on the way how we govern ourselves. Vulnerability may be either a condition that brings us closer and opens us up to the demands of acknowledgement of alterity, or the neoliberal form of regulation, control and power that orients and determines our field of actions, threatening us with unsafety and chaos (Tommasi, 2014). Neoliberal governmentality requires precariousness and vulnerability as a way of life, as an organizing and controlling principle in the root of biopolitical practices.

Under such prism, we intend to point here the ambivalent dimension of vulnerability and its biopolitical and biopotent activity. Therefore, in a second movement, following a reflection on the biopoliticity of institutional framing of impoverished subjects, we go on to briefly exhibit some photojournalistic framings able to configure a biopotency of stigmatized ways of life. In such framings it is possible to see agency and resistance in vulnerability, as well as tangible possibilities for configuring a political and troubling force in the images. 


\section{Biopolitcs and governmentality of impoverished bodies}

According to Fassin (2009) and Lazzarato (2014), biopolitics is connected to concrete experiences in which individuals are either treated with justice or injustice, depending on varying principles and moral codes, often leading to inequalities and lack of acknowledgement. Both authors emphasize, following Deleuze and Guattari, that life and the living being are the nodal point of the new political struggles. In this sense, beyond institutional frames, it is the narratives and communicative exchanges engendered by them what should become the object of investigation of such researches focused on unveiling the power flux that, under the pretext of "empowerment"; "emancipation" and "sovereignty" of marginalized subjects, end up exposing and deepening violence, moral suffering and identity damages.

The concept of biopolitics comes up in 1976, used by Michel Foucault in the first volume of History of Sexuality. Initially, Foucault (1980) explains the transition from sovereign power (which brings death and lets live) towards biopower (which brings life and lets die): they consist in two different regimes, two conceptions of death, life and body. In societies governed by sovereign power, the rule was "the right to apprehend things, time, bodies and, finally, life: culminating with the privilege of seizing power over life in order to suppress it" (Foucault, 1980, p. 128).

As sovereign power shifts into biopower, power ceases to be majorly based on the control and appropriation and begins to work through incitation, reinforcement, surveillance, so as to improve the forces subdued to it. In this new regime, power is described by Foucault as "police", i.e. a range of government techniques designated to produce forces that must stimulate life, creativity and productivity not free from rigid control and limits ([1977] 2003). Biopower must manage life without demanding death and, when it does demand death, it is in name of the defense of life (a justification often presented in case of wars or invasions committed by the U.S.A.). Under this aspect, political power takes on the task of managing life, investing on it (administration of bodies and calculating management of life). So biopower concerns the government of bodies through the rationalization of the art of government that

INTERIN, v. 25, n. 1, jan./jun. 2020. ISSN: 1980-5276.

Ângela Cristina Salgueiro Marques; Alexei Padilla Herrera. Biopolitical Frames of Impoverished Women in Journalistic Photography about the Bolsa-Família Program. p. 27-56. DOI 10.35168/1980-5276.UTP.interin.2020.Vol25.N1.pp27-56 
affects the ways of life, once it seeks the normalization of people through political technologies (Fassin, 2009).

In the text "Omnes et Singulatim" ([1981] 2003), Foucault relates biopolitics to the way "police" and politics represent different ways of ensuring order and strengthening the state. For him, the birth of politics happens within the scope of government (management practices). His main interest lies in discovering the rationalities of government, i.e. the police. The police in Foucault are defined as "an art of governing and a method for analyzing a population living in a territory" ([1981], 2003, p.384). This definition of politics is clearly connected with the maintenance of biopolitics, but also with an ethics of resistance which opposes, in perpetual negotiation, the government techniques and the self appropriation techniques (Foucault, 1994). The object of the police is the life of the population, the life in society of living individuals. Thus, the police expresses concern about the welfare of the subjects and their surroundings (for example, those who are in health produce more), articulated with the support of the power to govern the state itself.

\begin{abstract}
Assuring health and provisions, the police apply themselves to preserve life; with regard to commerce, factories, workers, the poor and public order, it deals with the comforts of life. Watching for the theater, for literature, for spectacles, its objective is none other than the pleasures of life. In short, life is the object of the police: the indispensable, the useful and the superfluous. It is up to the police to allow men to survive, live and do better. (Foucault, [1981] 2003, p.381)
\end{abstract}

Foucault divides (considering the $18^{\text {th }}$ century on) the organization of a governmental power over life in two poles: body discipline (taming, widening abilities and domestication) and population control (biopolitics). Biopolitics gains shape around the mid- $18^{\text {th }}$ century and is focused on the biological government of collective bodies: the control over proliferation, birth rates, mortality, health level, life expectation and longevity. The combination of disciplinary practices with biopolitical practices aims at the controlled insertion of subjects into the capitalist machine of production, increasing the chances of adaptation to the needs of the market and also the framing of bodies and subjectivities (Lazzarato, 2002). Foucault refers to life from 
the perspective of behavior, biopower in terms of the discipline exerted on individuals and biopolitics in terms of technologies normalizing populations.

There is a difference between disciplinary society (institutions prescribing behavior) and society of control (Deleuze, 1992) (controlling mechanisms are more democratic, immanent to the social field, diffused in the brain and body of citizens). Power invests life by crossing it over head to toes. The individual body is submitted to surveillance and, next, population is controlled, accommodated and governed according to procedures, techniques and methods that allow the ordinary exercise of forms of control, regulation and coercive orders. Discipline has prepared the individual bodies for the biopolitical management whose objective is to organize collective life, protect it and warrant its defense, so as to correct its flaws and frame it in a preestablished formats seen as normal (Hardt; Negri, 2000).

Finally, society of control could be characterized by the intensification and generalization of normalizing apparels of discipline that bring life, from inside, to our common and ordinary practices. But, opposed to the discipline, such control "extends beyond the structured spaces of social institutions, through light, moldable and fluctuating networks" (Hardt; Negri, 2000, p. 17). Biopower is, therefore, a form of power that conducts and rules social life from its interior, following it, interpreting it, assimilating and reformulating it.

What is at issue are governmentalities, that is, the forms of rationality that organize the ways of being and doing things, on the one hand, and the freedom to act and modify the rules of the game (albeit partially), on the other hand. Moreover, what governs the subject and collectivities always has as a counterpart a reflection on how to resist control (biopuissance).

\section{Vulnerability as biopolitical control or way of resistance?}

The analyses developed yielded from Marques's $\mathrm{PhD}$ research, in which she evaluates, between 2003 and 2007, the deliberations about the Program in press and television media, as well as in the spaces of ordinary conversation occupied by women

INTERIN, v. 25, n. 1, jan./jun. 2020. ISSN: 1980-5276.

Ângela Cristina Salgueiro Marques; Alexei Padilla Herrera. Biopolitical Frames of Impoverished Women in Journalistic Photography about the Bolsa-Família Program. p. 27-56. DOI 10.35168/1980-5276.UTP.interin.2020.Vol25.N1.pp27-56 
recipients in the cities of Campinas and Belo Horizonte (Marques, 2009, 2010). Along the research, we gathered around 76 images from journals with wide national circulation, ones that kept digitalized data accessible to the public, such as Folha de S. Paulo, Estado de S. Paulo, and O Globo. Such images portray male and female recipients of the Program, orienting our work of analyzing the frames used by the media for constructing the arguments that fed social debate. Taking the collection of such images to a wider time scale and restricting the scope to the representation and framing of female recipients, we reached between 2003 and 2015, a total of 120 images, among which I chose a few for composing the reflection proposed in this text.

Among the 120 images collected in newspapers and printed magazines, we selected to analyze here six images that we deem exemplary to demonstrate the stages of implementation of the Bolsa Familia program and its linkage to what we know as the "feminization of poverty"3. Thus, two great moments can be seen in the press photographs that were broadcast. Like a "before and after" transformation that meets the guidelines of the exemplarity of a project that is fulfilled, the women photographed and who represents the central characters of Bolsa Família in the press, go from a situation of "extreme poverty" to the one considered better, the (which need to be overcome as weaknesses rather than dimensions that inform resistance practices), so as not only to demonstrate the effectiveness of the program, but also to justify its permanence as a successful emergency action, but still needed in order to improve what persists of the difficulties faced in their lives.

We started from the assumption that certain images of poverty and impoverished women, and their different framings produced by both traditional media and public institutions, as they orient behavior, configure a form of neoliberal governmentality (Fassin, 2010, 2015; Rago, 2017) structuring these women's occasional field of action. Therefore, the appearance of impoverished subjects in

\footnotetext{
${ }^{3}$ Women are holders of the Bolsa Família Program (the bank credit card to receive the assistance is made on their behalf), as well as the institutional social assistance agents responsible for locally registering and monitoring the beneficiaries. The webs of relationships that unite these social agents are sustained by logics that move within moral economies, biopolitical rationalities and specific resistances. We cannot let to mention the centrality of the notions of social vulnerability, care, responsibility and family, all crossed by an ideological process of moralization that includes self blaming, meritocracy and citizenship conceived as a gift.
}

INTERIN, v. 25, n. 1, jan./jun. 2020. ISSN: 1980-5276. 
institutional media images involves a delicate operation of framing the framework (Butler, 2015), that is, an interpellation aiming at the cracks that indicate that the frame does not manage to determine the precise way how we see, think, acknowledge and learn. Besides, the frames that make marginalized subjects visible in media discourses usually contribute to intensify precariousness and invisibility.

The first image we wish to analyze illustrates a report from the early 2003, year in which Fome Zero Program [hunger eradication program] is presented to the Ministry of Social Development and little by little is converted into the Bolsa-Família Program. We see, on the foreground, a donkey, behind it a woman carries a vase of water (we cannot deny the religious element of this image and the association with Vierge Mary) and, on the background, the presence of elements that routinely feature the imaginary framing of misery in Brazil: the dry soil and vegetation, a very humble house and the oppressing light of heat in the Northeast. It is worth emphasizing that the city of Guaribas is pointed as the program's "ground zero", for it was the first city to be benefitted by the program.

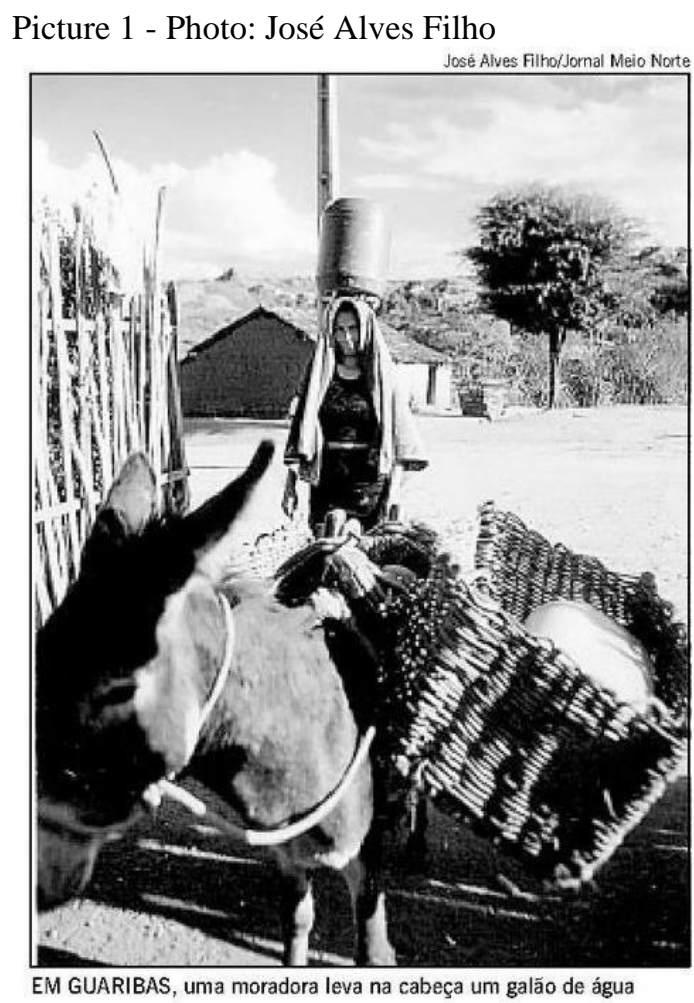

Source: RIBEIRO, Efrém. "Fome Zero expõe a face cruel da miséria" ["Fome Zero exposes the crue face of misery"], $O$ Globo, O País, 01/29/03, p.8.

Subtitle: In Guaribas, local woman carries a water vase on the head

INTERIN, v. 25, n. 1, jan./jun. 2020. ISSN: 1980-5276. 
This kind of framing does not allow us to clearly see the woman's face, hidden by a piece of cloth and silenced by the elements of the landscape, configuring a predominant reading on who are the poor people who must be helped by the government and where they live. There is also a possible interpretation deriving from this image: the donkey, the woman, the house and the oppressive landscape, overlaid, lead us to think of an "animalized" life, in the sense of the lack of autonomy, speech, alternatives and choices rather than those offered by "divine" assistance or the "good deeds" of the government. The aesthetics of poverty, in black and white, turns misery into art without deconstructing the frames of meaning that lead us to apprehend poverty through a moral dimension that evaluates and judges the ways of life and existence.

Somehow, the isolation and oppression yielding from this image also feature image 2. The two images may be seen as an emblem of the average register of the situation of female recipients of the Program between 2003 and 2009, since in this period the frames tend to dissolve the bodies in the landscape so that the conditions and possibilities of subjectivation seem to be determined by their previous geographic insertion, and by ideologies that insert and restrict the northeastern woman to the domestic context, to motherhood and subservience to the husband. One may understand such images as the synthesis of a narrative associating poverty, drought, northeast and dependence, originated by a representative system and relations established a priori that define the way of presentation and figuration in a specific narrative on the poor and the poverty. 
Picture 2 - Photo: Acervo da FSP

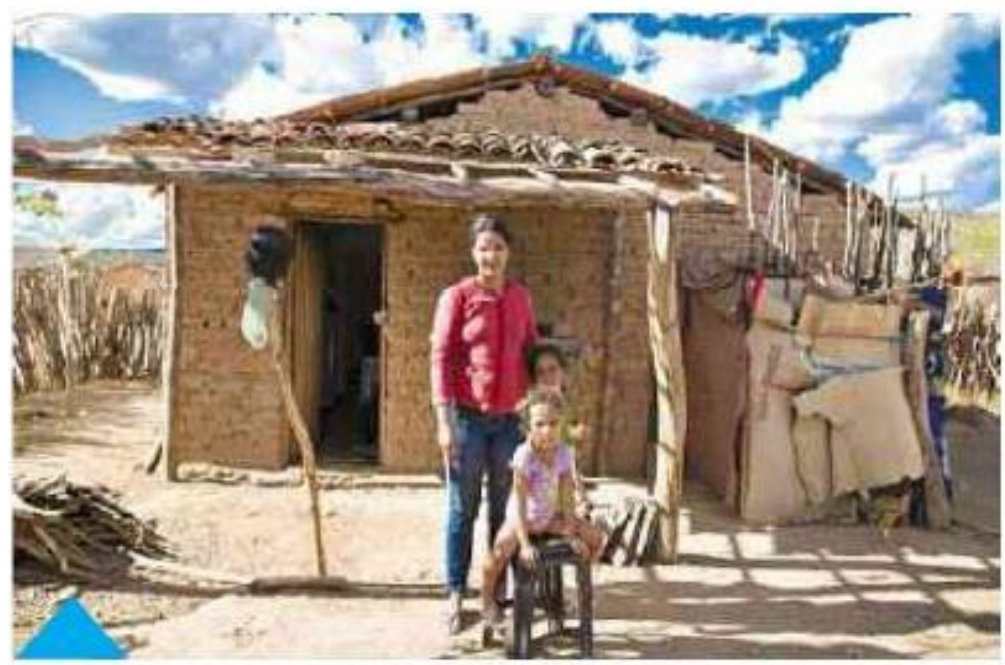

À ESPERA Edineide Dias, 25, e as filhas Graziele, 4, e Natieli, 5, ainda sem Bolsa Família; leite, só 3 vezes por semana, diz a mãe

Source: MAISONNAVE, Fabiano. "O excluídos do marco zero" ["The outcasts of ground zero"], Folha de S. Paulo, Brasil, 12/10/2014, Eleições 2014, p. 8.

Subtitle: Waiting: Edineide Dias, 25, and her daughters, Graziele, 4, and Natieli, 5, still wait for Bolsa Família; milk, only 3 times a week, says the mother.

It is very important to emphasize that the analyses developed here do not intend to reduce the complexity involved in the operation of Bolsa-Família Program to the frameworks produced by the media. In works previously developed (Marques, 2009; Marques, 2010) we show how the communicative dynamics, the dynamics of production of political autonomy and redistribution of resources associated to social acknowledgement promoted by this program is essential for the political subjectivation of impoverished women. The point here is not to demote the various merits of this social program, but to evidence various ambiguities and oppressive framings featuring the configuration of its images.

One of these oppressive elements can be related to the way women are reduced to the role they play in motherhood. As pointed out by Fineman (1991), the different discourses on poverty and impoverishment characterize women as mothers, wives, caregivers, essential assets in maintaining family life. Family ties considered as "deviant" (single mothers, homosexual couples, divorce, absence of marriage contract, etc.) are referred as cases without legitimacy to obtain support from public policies that privilege, reiterate and value normativities. Thus, a technical form of

INTERIN, v. 25, n. 1, jan./jun. 2020. ISSN: 1980-5276. 
governmental rationality in the collective management of impoverished women and mothers consists in affirming their function of reconstituting and maintaining the balance of familial bonds and its predominantly patriarchal structure. Fineman describes in detail the mechanism of biopolitical regulation that acts on the behavior of mothers:

\begin{abstract}
When a woman becomes a mother she performs a valuable societal function. She is reproducing to the benefit of the state, the workforce and the family. The significance of her task historically has been the justification for subjecting her as "mother" to state power. She is supervised and judged according to standards that do not apply to other citizens. The behavior of mothers is regulated through the companion normative systems of law and family ideology. If mothers are found wanting, they may be punished. This is particularly true for poor and single mothers, but all women as mothers risk intervention and subjugation based on their status. State-imposed supervision and control of mothers, and the corresponding sacrifice of privacy, should form the basis for an entitlement to justice by mothers-a claim for the resources to perform the tasks society demands of them. (FINEMAN, 1995, p.2211)
\end{abstract}

Unlike the previous figure, color photography purposely helps to highlight the different objects that are presented; cardboard, clothing, plastic bag, intensely lit blue sky, house and floor of the same color as if they were made of the same material. The woman, identified only as a mother, is standing next to her daughters, all in pose pinned to the camera. The mother devoid of face is a central element of rhetoric and a discursive framework that reinforce governmental and institutional techniques of curtailing and controlling the behaviors and actions of impoverished women. According to Fineman (1995), such gendered ideologies reinforce the understanding that the problems and vulnerabilities faced by impoverished women would be derived from their own behavior, reducing their existence to the simplistic and negative assessment that judges women who are mothers in their responsibility or irresponsibility, according to the status of their relationships with men. ${ }^{4}$

\footnotetext{
4 "What have these women done to "deserve" such harsh words and punitive measures? In large part it is the stigma of being poor. But more than poverty is at issue. The broad general target is unmarried women with children, and the attacks on these mothers are the opening salvo of a reactionary plan to discipline women who do not conform to the roles they are assigned within the traditional scheme of the family. This is why all women, whether they are mothers or not, should be concerned with the current debate about poverty. Although the welfare debate seemingly stigmatizes only one form of mothering as pathological, political rhetoric reinforces, recreates, and reiterates several fundamental premises about families that will be used against all women. Paramount among these is, of course, the
}

INTERIN, v. 25, n. 1, jan./jun. 2020. ISSN: 1980-5276. 
Another one of such ambiguities may be verified in image 3: it reveals a change in the framing of female recipients between the years of 2010 and 2013. One focuses now on the female body on the foreground in a frontal shot - one may now properly visualize the face in the portrait - usually placing a woman in a domestic context (inside or outside the house, but the house remains a central element of the scenario), often emphasizing the body from bottom up (empowerment), and others top down (subjection).

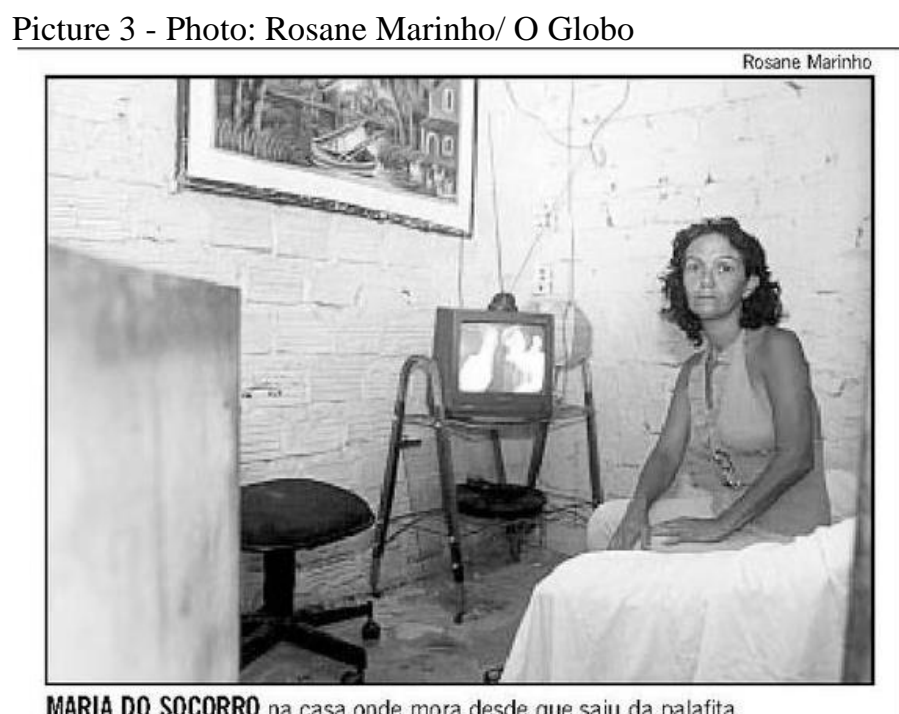

Source: RIBEIRO, Efrém. Um ano depois, nos emblemas da miséria [A year later, the emblems of misery] -, O Globo, O País, 01/11/04, p.14.

Subtitle: Maria do Socorro in the house where she lives since she left the stilt house

Women are given a name, some direct quotations in the body of the text of the article, but still figure narratives that present them as heroines of everyday life, examples to be followed, whose merit is unquestionable. Picture 3 shows an exemplary woman, evaluated by journalistic discourse as "deserving" the benefit for having conducted her life with dignity, despite extreme poverty. Specifically, this image reveals how, in the first year after the institution of the Program, recipient women were

strong preference for formally celebrated heterosexual marriage that functions as a reproductive unit and is thus the "core" upon which all else is founded. [...] Motherhood outside this family unit will be punished and stigmatized. Nonmothers will also be disciplined, pressured and pitied. (FINEMAN, 1995, p.2197).

INTERIN, v. 25, n. 1, jan./jun. 2020. ISSN: 1980-5276. 
much more "compelled" to prove their condition of precariousness in order to have access to the benefit.

To expose oneself, to expose precariousness, to report it in narratives of vulnerability as a destroyer of agency and of the possibility of subsistence, standard formularies and interviews with social assistants are examples of biolegitimating processes in which the body is used as a "source of rights", in a kind of a priori demand, pre-condition to the access to social policies. The more deteriorated the bodies and homes, the fitter seem to be as recipients of the benefit. Institutional agents not rarely demand narrative or physical proofs of struggle, failure and incapacity in order to justify the need, mixing merit and compassion. Affections and laws, pity and justice come to be outlined in each analyzed "case". A modality of biopolitical government is installed in which precarious bodies are fundamental. Under this aspect, Fassin (2015) argues that a combination between management policies and policies of suffering (based on the requisition and collection of narratives of failure, associated to compassionate treatment) leads to a redefinition of moral economy ${ }^{5}$ in our times.

This biopolitical and vulnerable-making framework imposed on women features a kind of violence that condemns and sentences the guilty ${ }^{6}$. As if such women were less worth of value than those who manage to face and sustain a gaze towards the reader who supposedly interrogates and evaluates her conduct. As highlighted by Fassin:

The institution of redistributive policies always implies forms of moral judgment on the way how people lead their lives, both in the macrosocial level of the board of legislations and procedures, and the microsocial level of particular decisions one takes face to individual situations. [...] Biographies are scrutinized in search for elements that attest the good

\footnotetext{
5 "Moral economies represent the production, circulation and appropriation of values and affections around an issue. They characterize a particular historical moment and specific social world in which this issue is constructed through judgments and feelings that gradually define a kind of common sense and collective understanding on the problem. Moral economies do not characterize a specific group or activity, but a social fact" (Fassin, 2015, p. 9).

${ }^{6}$ We notice that, in general, biopolitical frameworks connected to the promotion of social policies articulate through characters usually configured by two specific molds: a) characters described as heroes of everyday life, whose exemplary lives have dignity, merit and are morally preserved from the condemnation driven to those who act with malice (frame of meaning used for condemning those who are indicted as fraudsters of the benefit); and b) subjects with no voice, name or history, offering what would be a line of flight open in the unavoidable route of failure and poverty.
}

INTERIN, v. 25, n. 1, jan./jun. 2020. ISSN: 1980-5276. 
conduct of recipients in order to give them what they should be entitled to. (2010, p. 108-109).

The gift represented by the assistance becomes, then, rather and obligation than a right, besides authorizing an investigation on their lives so as to make a theme of the effort or failure in the search for jobs, live improvement, demonstrations of responsibility and ethics towards children, society and management of financial resources. When it comes to portraying women around the themes of fraud or malice in the use of resources it is possible to see the action, via media framing, of the punishment inflicted by society to moral conduct seen as reprehensible.

In our corpus, many photojournalistic images ascribe visibility to BolsaFamília and its indexes of success translate female emancipation as individual and meritorious economic success, hardly revealing the contingencies that cross over the rank of experiences and choices available to the impoverished woman. The ideological acknowledgement of such woman as responsible, creative and entrepreneur influences the way how she configures her project of life, adapting it, not rarely, to the needs of neoliberal governmentality rather than her own ones (Rago, 2017).

Besides, in the case of women, as pointed out by Rago, neoliberal governmentality composing the ideological aspect of such policies defines women under the optics of private entrepreneurialism (Tommasi, 2014; Cabanes, Georges, 2014) as "subjects capable of free choice, based on a rational economic calculus, for, as much as men, they have been called to subjectivate themselves in neoliberal ways, constituting themselves as autonomous and emancipated" (2017, p. 368). In neoliberal reasoning, redistribution promotes women to the optimizing model of "self-investor", and acknowledgement is turned into a form of precarious and subdued "self-report".

Fassin (2015) calls biolegitimacy the way how the access to governments' social policies takes place nowadays. According to him, the production of rights, acknowledgement and access to services and assistance from the State, are connected to the way how the State offers assistance to precarious subjects, that is, by demanding from the recipients enunciates and formularies that may attest a kind of status, condition, internalization of dependence and total rendition to the apparels of control and correction:

INTERIN, v. 25, n. 1, jan./jun. 2020. ISSN: 1980-5276.

Ângela Cristina Salgueiro Marques; Alexei Padilla Herrera. Biopolitical Frames of Impoverished Women in Journalistic Photography about the Bolsa-Família Program. p. 27-56. DOI 10.35168/1980-5276.UTP.interin.2020.Vol25.N1.pp27-56 
What politics makes of life and lives is not only a matter of discourse and technologies, strategies and practices. It is also a matter of the concrete way how individuals and groups are treated, under which principles and in name of which moral, implying inequalities and lack of acknowledgement (Fassin, 2009, p. 57).

Face to such aspects, Fassin emphasizes that social public policies play nowadays a fundamental role in the biopolitical management of bodies and ways of being, characterizing a governmentality that corresponds to the rationalization of the art of governing and not to the practice of government. We critically question the tension between two processes that give shape to this program: on the one hand, there is substantial improvement in the life conditions and autonomous agencies for managing one's one well-being. On the other, the discourse of government's public communication and traditional journalistic media insist on presenting, very often, stigmatizing representations of recipient women modeled by biopolitical frameworks of control, destining them to a place of speech previously marked by devaluation and prejudice. The ordinary drama of female vulnerability would be, therefore, easily acknowledgeable in such images socially favorable to the adherence to the Program that translate female emancipation as individual and meritorious economic success, hardly revealing the contingencies that cross over the experiences and choices available to the impoverished woman (Marques, 2017).

In the images we collected, we realized that the photographed subjects have no other choice than using their own bodies in order to evidence and narrate their lives, either in agreement with frameworks appreciable by the biopolitics of management of poverty and precarious populations, or for revealing the misfits and the ways of capture and control by governmental and media apparatus. So, to look at a female body discursively produced as precarious and exposed in a journalistic photograph implies exploring the discursive forms of biopolitical framework that accentuate their disappearance, as well as seeking vestiges of resistance, revelations that may evidence how they find ways of preventing the labelling of their faces and bodies, creating gaps, dissonances and dissent between their "apparition" and the narrative (visual and verbal) register of their exposition.

INTERIN, v. 25, n. 1, jan./jun. 2020. ISSN: 1980-5276. 


\section{For a politics of vulnerability in media frameworks}

The discourse of biopolitical governmentality foments the understanding that vulnerability must be seen as rare or as a sign of weakness, an unfortunate accident a necessary fiction that makes viable a certain social and political order, confirms exclusion, maintains inequalities. This imaginary, or fiction of invulnerability, features the fact that laws, social and media frameworks, value and evaluating schemes to which we submit designate categories of vulnerable people, defined by their supposed physical frailty, or also by their questionable autonomy or precarious ability for deciding and making choices (Ferrarese, 2016). Biopolitical frameworks also contribute to this fiction by producing conceptions of risk and merit, redefining vulnerability as a zone of susceptibility to multiple causes and by associating it to a logic of accumulation of social deficiencies which would be overcome by personal effort and merit.

So, to deny vulnerability and exalt invulnerability has become the greatest target of social and media representations and frameworks serving the capital and a certain balance in the correlation of forces that may favor certain subjects, groups and institutions, while leading others to ostracism, humiliation and death.

Vulnerability would be, then, a concept associated to passivity, poverty, violence, disaster, brutal death, insecurity, denoting a spectrum of negative conditions, disabling qualities and limited capacities, including underdevelopment, abject poverty, violation, injury, frailty, deficiency, dependence, a flaw that prevents selfaccomplishment and collective accomplishment (Cole, 2016). The frequent opposition between vulnerable/invulnerable produces very strict social and gender hierarchies following fix social identities anchored in judicial or normative forms of distinction between capable and incapable, apt or inapt, functional or dysfunctional subjects. Attempts at disciplining those pointed as vulnerable are put to practice by many neoliberal political segments, culminating in isolated and individual attributions of responsibility, and in the production of victims.

INTERIN, v. 25, n. 1, jan./jun. 2020. ISSN: 1980-5276.

Ângela Cristina Salgueiro Marques; Alexei Padilla Herrera. Biopolitical Frames of Impoverished Women in Journalistic Photography about the Bolsa-Família Program. p. 27-56. DOI 10.35168/1980-5276.UTP.interin.2020.Vol25.N1.pp27-56 
It is important to emphasize that ontological and social vulnerabilities are not isolatable and they all manifest and are constituted in situations: structural injustices are caused by the context and ordinary practices, but also by institutions, their arrangements and circumstances, which always protect certain individuals while exposing others to different forms of events and damage (Ferrarese, 2016).

Judith Butler (2016), when commenting such unequal distribution of vulnerability among individuals and groups, emphasizes the importance of thinking on the resignification of this concept, allowing one to acknowledge the emergence of singular experimentations in the situations of vulnerability, ones that are not grasped and mapped by the rule, when one may see the rise of new ways of life outside disciplinary regulation, the effectivity of a shared becoming that, tentatively, communication and interdependence seek to construct.

So, when Butler (2011) defines vulnerability, she has in mind the place occupied by a subject in a set of relations marked by a field of objects, forces, vital processes, institutions and beings who affect her somehow. Vulnerability thus understood reveals a way of being in the world and living a life constituted in between our passibility (being affected by happenings) and our capacity of agency.

While in neoliberal ideology the adjectives "vulnerable" and "precarious" are generally used for stigmatizing and regulating (due to the syntax of risk and selfgovernment/self-control), as a heuristic category vulnerability seems to meet wider efforts at politicizing injury and suffering. Under this aspect, the vulnerable political subject cannot be defined as a victim, a dependent, dispossessed. Vulnerability is not a concept essentially associated to suffering, nor does it define only a tendency for being susceptible to damage. There is potentiality and ambiguity in this concept.

In order to escape such biopolitical syntax and show the potentialities of this conception, philosophers such as Lazzarato (2006) proposes a different understanding of precarious and precariousness as one of the dimensions of vulnerability. Instead of the destitution of the capacity of agency or the idea that a large extent of our capacities and efforts at action would be developed against unavoidable vulnerability, he proposes that a life may be defined as "precarious" not only in the sense of material and symbolic destitution, but as someone whose identity oscillates among many names

INTERIN, v. 25, n. 1, jan./jun. 2020. ISSN: 1980-5276.

Ângela Cristina Salgueiro Marques; Alexei Padilla Herrera. Biopolitical Frames of Impoverished Women in Journalistic Photography about the Bolsa-Família Program. p. 27-56. DOI 10.35168/1980-5276.UTP.interin.2020.Vol25.N1.pp27-56 
and, therefore, escapes the classificatory mechanisms that define which lives deserve or not to be pointed as dignified.

Lazzarato (2006) points that the precarious subject is often described as part of a bank of data indicating poverty, unemployment, failure. However, according to him, the precarious one remains undefined, at the borderline between worker and unemployed, artist and bricoleur, configuring a way of life in which "relations are not codified, for they are, contradictorily and simultaneously, a source of political subjection, economic exploitation and opportunity to be seized" (2006, p. 218). According to him, the precarious discloses a subject not yet completely codified by neoliberalism and, therefore, not institutionalized and normalized, having the chance to construct multiple fights for her (becoming) identities.

In the following images, we believe to see the possibility of break-down, displacement from biopolitical governmentality featuring the frameworks of BolsaFamília evidenced so far. In the narratives produced despite the detail, it would be possible to grasp inadequacies that allow one to glimpse at forms of life and ways of signification found for expressing the routine experiences of the recipients of the program. We believe that, in the triviality of the elements that configure images of impoverished people and landscapes, there may exist an unforeseen gesture against the discursive design of public and social policies that now plays a fundamental role of biopolitical management of bodies and ways of being.

\section{In the thickness of ordinary life, the biopotent vulnerability}

After 10 years of Bolsa-Família, in 2013, many journalistic reports were produced in order to reveal its conquests and flaws. This year, besides the three newspapers that already featured our databank, we decided to collect other photojournalistic images from different sources, including magazines such as Veja, Istoé, Carta Capital and Nova Escola (the choice of this last one is justified by the fact that one of the main conditions of the program, and therefore, a parameter for evaluating its success, was related to the families compromising to keep their children

INTERIN, v. 25, n. 1, jan./jun. 2020. ISSN: 1980-5276.

Ângela Cristina Salgueiro Marques; Alexei Padilla Herrera. Biopolitical Frames of Impoverished Women in Journalistic Photography about the Bolsa-Família Program. p. 27-56. DOI 10.35168/1980-5276.UTP.interin.2020.Vol25.N1.pp27-56 
in school). We did not accomplish a systematic search, but a general gathering of reports related to Bolsa-Família.

One of the reports, published by magazine Nova Escola in $2015^{7}$ featured eight images $^{8}$ of recipient families among which two images particularly drew our attention. The first of them (see picture 4) shows the interior of the house of Maria do Carmo Oliveira Alves, citizen of Itatira (State of Ceará), mother of seven. In a previous image, Maria do Carmo and the children are photographed in front of the house, composing the typical framing ascribed to poor recipient families: the scenery of desolation, aridity and struggle is more important than the singularity of the subjects (their faces and bodies are dissolved in the landscape). In this image, in a composition that combines light and darkness (penury and hope), the focus is the wood-burning stove, the beam of light penetrating the kitchen by the roof, the entrance door with cracks that let the day light in and turn the house and the intimacy pervious to the world, the utensils on the sink and hanging from the brick wall.

\footnotetext{
${ }^{7}$ CAMILO, Camila. "Bolsa-Família: mais alunos, menos pobreza - como o programa e a frequência escolar obrigatória afetam o ensino" ["Bolsa-Família: more students, less poverty - how the program and obligatory school presence affect education"]. Published in NOVA ESCOLA Edition 278, December 2014/January 2015. Available at: $<$ http://revistaescola.abril.com.br/politicas-publicas/bolsafamilia-mais-alunos-menos-pobreza-beneficio-educacao-820093.shtml\#ad-image-0>,

Accessed $02 / 12 / 2015$.

${ }^{8}$ In general, when an essay emphasizes unhealthy conditions and struggles, the framing of the photographs favors a general shot of families in front of the house, highlighting the human and geographic landscape of desolation. But when the intention is to emphasize the protagonism of women and conquests obtained via combined actions of national and city government, the framings show closeness: the faces and bodies of women and children come to the foreground and the domestic environment is left aside or minimized in the image.
}

INTERIN, v. 25, n. 1, jan./jun. 2020. ISSN: 1980-5276. 


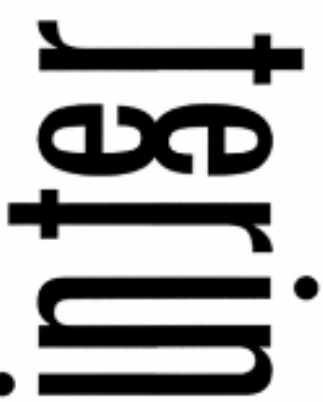

Picture 4 - Photo: Anna Rachel Ferreira/Nova Escola

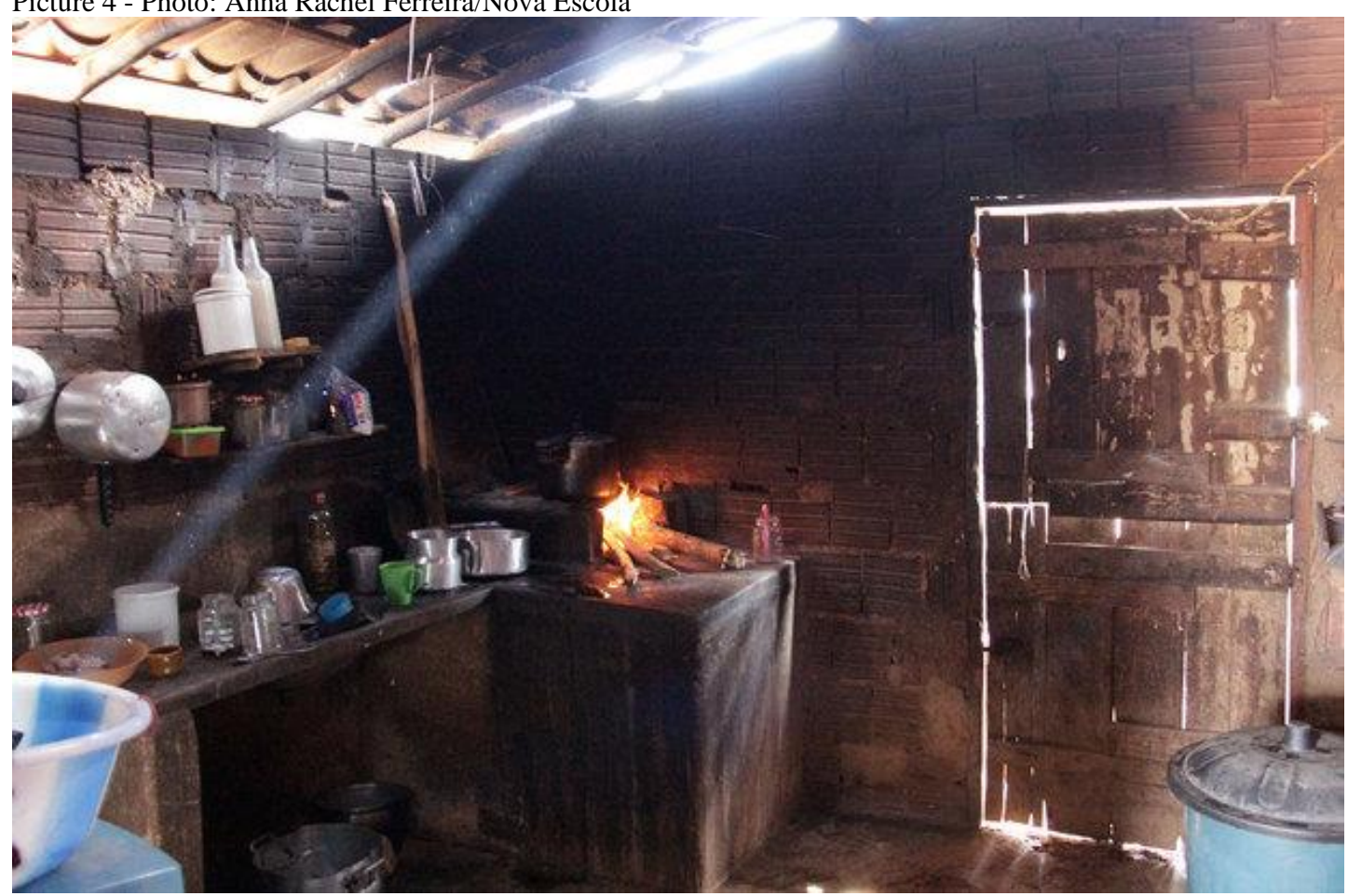

Subtitle: Life in poverty - though receiving the benefit, Maria do Carmo and her children live on limited resources. In the house with no coating, scarse utensils pile up on the sink

Source: Nova Escola, Edition 278, Dec 2014/Jan 2015.

Image 5 shows the clothes of the nine children of Maria de Lurdes Castelo, who also lives in Itatira, "stuck" on a wooden fence. The many multicolored pieces, emptied from the bodies that animate them, still seem to be alive and, at the same time, dead, trespassed by stakes, as spoils of a war led in ordinary life. There is something aggressive in this image: usually clothes on a clothesline come to life with the wind hitting the fabric. But the line of stakes keeps the clothes from gaining movement, rebellion and lightness. 


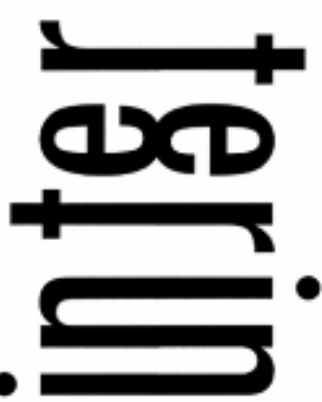

Picture 5

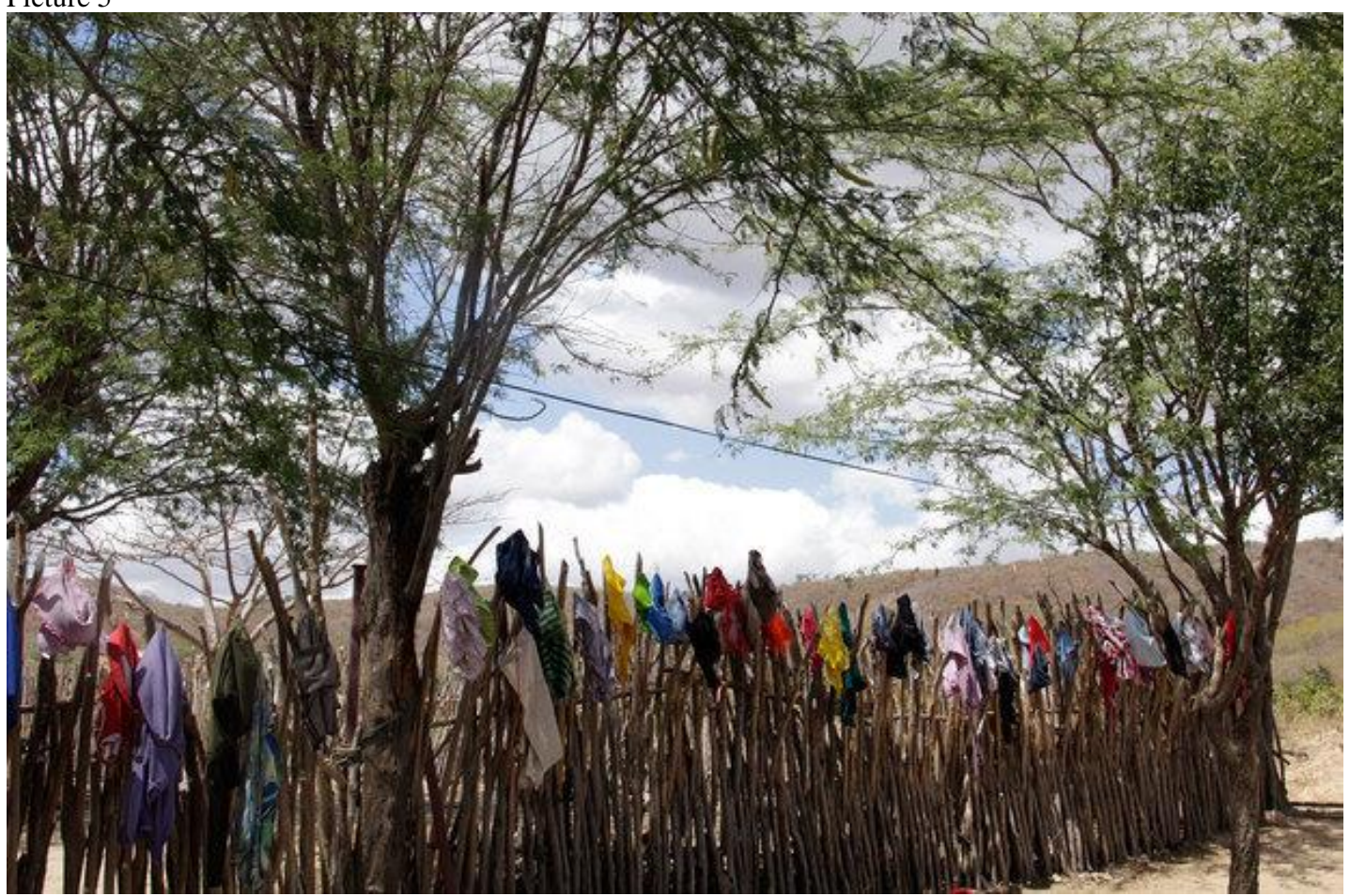

Subtitle: Simple life - The wooden fence besides the house is used as a clothesline for the nine children who wear them to go to school. The mother incentivates the children to study and seize opportunities.

Source: Nova Escola, Edition 278, Dec 2014/Jan 2015.

Both images, as they focus the objects and their disposition in ordinary spaces of living and existence, lead us to think on how photojournalism may, in some circumstances, offer frameworks in spaces and landscapes but also their connection with the ordinary. These images bring elements of dignity that define the existence of women and their children through their objects of ordinary use and "each of those things is part of an existence that is completely actual, unavoidable, and unrepeatable" (Rancière, 2011, p. 293). So, "realizing, even if minimally, these existences and their place in the world are only possible if we establish passages between the objects and the non-representable expressed in its effectivity" (Rancière, 2011, p. 294).

The poetics of ordinary life (Lopes, 2006) in these images derives from the focus on the worlds of intimacy, the house and the ways of inhabiting it and inhabiting the world. The small things and dramas are outlined in the space of the family, affection, protection and embrace of the frail demanding body. The poetic force of ordinary life and its objects resides also in its possibility of shaping the common, registering the multiplicity of ways of life and tracking the paths taken by 
impoverished subjects for making their worlds inhabitable in hope, but also in disappointment and despair. It is possible to think here on the definition of the aesthetics that orients the politics of vulnerability in Guattari's terms:

[...] aesthetics embraces all things that imply the permanent promotion of other agencies of enunciates, other semiotic resources, an alterity apprehended in its position of emergence (non-xenophobic, non-racist, non-falocratic), intensive and processual becoming, a new love for the unknown and for singularity, finally, a break-down on consensus (Guattari, 1992, p. 147)

According to Rancière (2012, p. 65), politics of aesthetics "consists in the elaboration of the sensitive anonymous world, ways of this and I, from which personal worlds emerge from political knots". This implies constructing other forms of common sense (data shared by all), other communities of words, forms and meanings. Other enunciates that may make the "visually trivialized territory of misery and margin be returned to its potentiality of sensitive and shareable richness" (Rancière, 2012, p. 78).

In both images, the framing gains its contours due to the potency (biopotency) of shaping what is common to the prosaic experiences of everyday life. They allow us to apprehend the other via fragments of her day and vestiges of her routine experiences: inhabited spaces, clothes that involve their bodies, utensils that warrant their survival. The potency of life that yields from it reveals a politics of aesthetics, a politics of the common, related to the form how the apparels used for producing journalistic images and texts have reached the possibility of clipping the objects of common experience in a singular way, creating new forms of sharing space and time and promoting new ways of apparition for the objects and subjects (Marques, 2013, 2014). This work of changing the ways of apparition, the coordinates of the representable and the forms of enunciation shifts the frames, rhythms and scales, allowing new forms of apprehending the visible and its meaning.

INTERIN, v. 25, n. 1, jan./jun. 2020. ISSN: 1980-5276. 


\section{Final remarks}

The biopolitical framework is a technique of government or governmentality that shapes the scenes of appearance preparing them to define exemplary subjects and groups, considered as parameters, whose design and way of life is considered as antithesis of the deviation and of morally judged existences as unworthy of consideration and appreciation.

Press photography, then, continues to participate as an operative model, on which exemplary poverty is based, constituting the repertoire of the poor subjects moral qualities and their correct representations. Thus, affections and laws, piety and justice are outlined in each case of life analyzed. A modality of biopolitical government is instituted in which the exhibition of precarious bodies becomes fundamental.

While the first images analyzed here sometimes turn the spectator into a judge of individuals taken as deserving or not the benefit, and other times build for them a place of passivity and surrender face to a victimizing framing of the "poor" and the "poverty", the two last images invite the glance to contemplatively go by the scenes of ordinary life, its objects and details, allowing a work of translation of the sensitive through the images offered by the image (Rancière, 2008).

The spectator of both images is placed at distance so that she may perceive what is "in between", so that she may be hosted by the images instead of "swallowed" or surrendered by them. In this gesture of separation and distance there is a gap that allows one to meet the other in the thickness of her experience.

Despite the differences that mark the images analyzed here, however much their pictorial and aesthetic elements often reaffirm frameworks of biopolitical control, we consider that, above all, these photographs are political, since it is not the content of the images that makes them political, but the sensitive transformations they produce in the way of looking, thinking and interpreting reality of those who contemplate otherness visually and textually disposed between us.

The female bodies and faces that appear in these images give rise to a collective political subject, mobilized not by an imposed social identity that declares its

INTERIN, v. 25, n. 1, jan./jun. 2020. ISSN: 1980-5276.

Ângela Cristina Salgueiro Marques; Alexei Padilla Herrera. Biopolitical Frames of Impoverished Women in Journalistic Photography about the Bolsa-Família Program. p. 27-56. DOI 10.35168/1980-5276.UTP.interin.2020.Vol25.N1.pp27-56 
precariousness, but by the challenge that they throw to the forms of police and economic power that incessantly constraints the chances that a life has to become livable and not only satisfied with survival.

\section{REFERENCES}

Biroli, F. (2018) Gênero e desigualdades: limites da democracia no Brasil, São Paulo: Boitempo.

Butler, J. (2011) "Vida precária", Contemporânea Revista de Sociologia da UFSCar, São Carlos, 3 (1): 13-33.

Butler, J. (2015) Quadros de guerra: quando a vida é passível de luto?, Rio de Janeiro: Civilização Brasileira.

Butler, J. (2004) Precarious Life, London: Verso.

Butler, J. (2016) "Rethinking Vulnerability and Resistance", in J. Butler, Judith; Z. Gambetti; L. Sabsay (eds) Vulnerability in resistance, London: Duke University Press, p.12-27.

Cabanes, R. ; Georges, I. (2014) Gestion de la pauvreté et enterpreneuriat de soi : un nouveau compromis de gouvernement au croisement des politiques sociales et néoliberales ?, Brésil(s), 4 (6): 7-15.

Cole, A. (2016) All of us are vulnerable, but some are more vulnerable than others: the political ambiguity of vulnerability studies, an ambivalent critique, Critical Horizons, 17 (2): 260-277.

Deleuze, G. (1992) Conversações, São Paulo: Ed.34.

Didi-Huberman, G. (2012) Peuples exposés, peuples figurants, L'Oeil de l'Histoire, v.4, Paris : Éditions de Minuit.

Fassin, D. and Memmi, D. (eds) (2004) Le gouvernement des corps, Paris: Éditions de l’École des Hautes Études en Sicences Sociales.

Fassin, D. (2004) Et la souffrance devient sociale: de l'anthropologie médicale à une anthropologie des afflictions, Critique: revue générale des publications françaises et étrangères, Paris, n.680-681: 16-21. 2004.

Fassin, D. (2001) Quand le corps fait la loi. La raison humanitaire dans les procédures de régularisation des étrangers, Sciences sociales et santé, Toulouse, 19 (4): 5-33.

Fassin, D. (2006) Souffrir par le social, gouverner par l'écoute: une configuration sémantique de l'action publique, Politix, Paris, 19 (73) : 137-157. 
Fassin, D. (2010). Évaluer les vies : essai d'anthropologie biopolitique, Cahiers internationaux de Sociologie, 128 (1): 105-115.

Fassin, D. (2009) Another politics of life is possible, Theory, culture \& society, 26 (5): 44-60.

Fassin, D. (2015) At the Heart of the State: the moral world of institutions, London: Pluto Press.

Ferrarese, E. (2016) The vulnerable and the political: on the seeming impossibility of thinking vulnerability and the political together and its consequences, Critical Horizons, 17(2): 224-239.

Fineman, M. (1995) Masking dependency: the political role of family rhetoric, Virginia Law Review, 81 (4): 2181-2215.

Foucault, M. ([1977] 2003) “A vida dos homens infames”, in M. B. da Motta, Manoel Barros da (org) Ditos e Escritos IV, Estratégia, poder-saber, Rio de Janeiro: Forense Universitária, p.203-222.

Foucault, M. ([1981] 2003) “Omnes et Singulatim”, in M. B. da Motta, Manoel Barros da (org) Ditos e Escritos IV, Estratégia, poder-saber, Rio de Janeiro: Forense Universitária, p.355-386.

Foucault, M. (1994) «Les techniques de soi », in: D. Deffert; F. Ewald; J. Lagrange (eds) Dits et écrits, 1954-1988, v.4, Paris: Gallimard, p.785-814.

Foucault, M. (1980) "Poder de morte e direito sobre a vida", in M. Foucault. História da Sexualidade, v.1, A vontade de saber, Rio de Janeiro: Graal, p.127-152.

Guattari, F. (1992) Caosmose: um novo paradigma estético, São Paulo: Ed. 34.

Hardt, M. and Negri, A. (2000) La production biopolitique, Multitudes, n.1: 16-28.

Lazzarato, M. (2002) Du biopouvoir à la biopolitique, Multitudes, n.9: 45-57.

Lazzarato, M. (2014) Signos, máquinas, subjetividades, São Paulo: Edições Senac; n1 edições.

Lazzarato, M. (2006) As revoluções do capitalismo, Rio de Janeiro: Civilização Brasileira.

Lopes, D. (2006) "Da estética da comunicação a uma poética do cotidiano", in C. Guimarães; B. Leal,; C. Mendonça (orgs) Comunicação e Experiência Estética, BH: UFMG, p.117-150.

Mackenzie, C.; Rogers, W. and Dodds, S. (eds) (2014) Vulnerability New Essays in Ethic and Feminist Philosophy, Oxford: Oxford University Press. 
Marques, A. (2009) A conversação cívica sobre o Bolsa Família: contribuições para a construção da cidadania e da autonomia política de mulheres pobres, Cadernos Gestão Pública e Cidadania, v. 14: 11-48.

Marques, A. (2013) Três bases estéticas e comunicacionais da política: cenas de dissenso, criação do comum e modos de resistência, Contracampo, v.26: 126-145.

Marques, A. (2014) Política da imagem, subjetivação e cenas de dissenso, Discursos Fotográficos, v. 10: 61-86.

Marques, A. (2008a) O Programa Bolsa-Família na mídia e na fala das beneficiárias: o lugar ocupado pelo Estado na configuração dialógica dos espaços de debate público, Eco-pós (UFRJ), v. 11: 166-191.

Marques, A. (2008b) Les enjeux médiatiques du Programme Bourse-Famille au Brésil : un processus de développement de la démocratie, Visages d'Amérique latine, v. 6 : 78-101.

Marques, A. (2009) A conversação cívica sobre o Bolsa Família: contribuições para a construção da cidadania e da autonomia política de mulheres pobres, Cadernos Gestão Pública e Cidadania, v. 14: 11-48.

Marques, A. and Farias, V. N. (2013) La reconnaissance sociale des minorités au Brésil depuis l'« Époque Lula », in: G. Uribe (Org.) Sociabilités, citoyenneté et liens sociaux en Amérique latine, 1ed, Rennes: Presses Universitaires de Rennes (PUR), v. $1: 139-162$.

Marques, A. (2017) A política das imagens e a pobreza. Mulheres do Bolsa-Família no fotojornalismo entre 2003 e 2013, Sur le Journalism, v. 6: 38-55.

Pelbart, P. P. (2002) Pouvoir sur la vie, puissance de la vie, Multitudes, n.9 : 25-35.

Rago, M. (2017) "Foucault, o neoliberalismo e as insurreições feministas", in M. Rago, and S. Gallo (orgs) Michel Foucault e as insurreições: é inútil revoltar-se?, São Paulo: Intermeios, p.363-374.

Rancière, J. (2004) Aux bords du politique, Paris: Gallimard.

Rancière,J. (2007) Le travail de l'image, Multitudes, n.28, p.195-210, 2007.

Rancière, J. (2012) O espectador emancipado, São Paulo: Martins Fontes

Rancière, J. (2011) Aisthesis, Paris: Galilée.

Rancière, J. (2008) "El teatro de imágenes", in A. Jaar. La política de las imágenes, Santiago de Chile: Editorial Metales pesados, p.69-89. 
Tommasi, L. de. (2014) Juventude, projetos sociais, empreendedorismo e criatividade: dispositivos, artefatos e agentes para o governo da população jovem, Passagens: Revista Internacional de História Política e Cultura Jurídica, v. 6: 287-311.

Recebido em: 20/09/2019

Aceito em: 22/10/2019 